\title{
Pengaruh Belanja Daerah dan Tenaga Kerja terhadap Output Sektor Swasta di Sumatera Selatan
}

\author{
Muhammad Bahrul Ulum., S.E., M.Si. \\ Universitas Indo Global Mandiri \\ Email: bahrulu1994@uigm.ac.id
}

\begin{abstract}
The purpose of this study was to determine the effect of regional spending namely direct and indirect spending, labor on the private sector in South Sumatra. The data used are secondary data in the form of time series 20062017 sourced from the DGT Ministry of Finance and the Central Statistics Agency (BPS) which have been processed. This research uses Multiple Linear Regression analysis method with Ordinary Least Square (OLS) method. The results of this study indicate that during 2006-2017 the expenditure variable directly had a positive and significant effect on private sector output in South Sumatra. The indirect expenditure variable has a positive and significant effect on private sector output in South Sumatra. Labor variables have a positive and significant effect on private sector output in South Sumatra. Overall independent variables have a significant effect on the output of the private sector in South Sumatra.
\end{abstract}

Keywords: Direct Expenditure, Indirect Spending, Labor, Private Sector Output

\section{Abstrak}

Tujuan penelitian ini untuk mengetahui pengaruh belnja daerah yakni belanja langsung dan belanja tidak langsung, tenaga kerja terhadap sektor swasta di Sumatera Selatan. Data yang digunakan adalah data sekunder dalam bentuk time series tahun 2006-2017 yang bersumber dari DJPK Kementerian Keuangan dan Badan Pusat Statistik (BPS) yang telah diolah. Penelitian ini menggunakan metode analisis Regresi Linier Berganda dengan metode Ordinary Least Square (OLS). Hasil penelitian ini menunjukan hasil bahwa selama tahun 2006-2017 variabel belanja langsung berpengaruh positif dan signifikan terhadap output sektor swasta di Sumatera Selatan. Variabel belanja tidak langsung berpengaruh positif dan signifikan terhadap output sektor swasta di Sumatera Selatan. Variabel tenaga kerja berpengaruh positif dan signifikan terhadap output sektor swasta di Sumatera Selatan. Secara keseluruhan variabel bebas berpengaruh signifikan terhadap output sektor swasta di Sumatera Selatan.

Kata kunci: Belanja Langsung, Belanja Tidak Langsung, Tenaga Kerja, Output Sektor Swasta

\section{Pendahuluan}

Pembangunan ekonomi merupakan suatu proses perubahan yang terjadi secara berkala dan bertujuan untuk meningkatkan pendapatan perkapita masyarakat selama periode tertentu. Pembangunan juga dapat dilakukan dengan membentuk suatu kerjasama antara pemerintah daerah dan sektor swasta yang bertujuan untuk menciptakan suatu lapangan kerja baru guna meningkatkan pertumbuhan ekonomi daerah. Dalam upaya untuk mencapai tujuan tersebut, pemerintah daerah dan masyarakatnya harus secara bersama-sama mengambil inisiatif membangun daerah. Oleh karena itu, pemerintah daerah beserta partisipasi masyarakatnya harus mampu menaksir potensi sumber daya yang diperlukan untuk merancang dan membangun perekonomian daerah (Arsyad, 1999)

Menurut Permendagri Nomor 25 tahun 2009 tentang penyusunan anggaran pendapatan daerah dan belanja daerah dalam hal penggunaan dana, belanja daerah terbagi menjadi dua yaitu belanja langsung dan belanja tidak langsung yang merupakan pengalokasian dana yang harus dilakukan secara efektif dan efesien, belanja daerah dapat menjadi tolak ukur keberhasilan otonomi daerah. Belanja tidak langsung terdiri dari: belanja pegawai, bunga, subsidi, hibah, bantuan sosial, belanja bagi hasil, bantuan keuangan, dan belanja tidak 
terduga, sedangkan belanja langsung merupakan belanja yang dianggarkan terkait secara langsung dengan pelaksanaan program dan kegiatan. Belanja langsung terdiri dari belanja pegawai, belanja barang dan jasa, serta belanja modal untuk melaksanakan program dan kegiatan pemerintahan daerah yang telah dianggarkan (Winoto \& Falikhatun, 2015).

Pertumbuhan ekonomi merupakan proses perubahan kondisi perekonomian suatu negara/daerah secara berkesinambungan menuju keadaan yang lebih baik selama periode tertentu. Pertumbuhan ekonomi juga dapat diartikan sebagai proses kenaikan kapasitas produksi suatu perekonomian yang diwujudkan dalam bentuk kenaikan pendapatan nasional. Adanya pertumbuhan ekonomi merupakan salah satu indikasi keberhasilan pembangunan ekonomi dengan harapan kesejahteraan masyarakat juga bertambah. Menurut Rahardja (2008) Pertumbuhan Ekonomi (Economic Growth) adalah perkembangan kegiatan dalam perekonomian yang menyebabkan barang dan jasa yang di produksi dalam masyarakat bertambah dan kemakmuran masyarakat meningkat. Perkembangan kemampuan memproduksi barang dan jasa sebagai akibat pertambahan faktor-faktor produksi pada umumnya tidak selalu diikuti oleh pertambahan produksi barang dan jasa yang sama besarnya.

Indikator yang digunakan untuk menghitung tingkat pertumbuhan ekonomi adalah tingkat pertumbuhan produk nasional, seperti Produk Domestik Bruto (PDB) untuk tingkat nasional dan Produk Domestik Regional Bruto (PDRB) untuk provinsi dan kabupaten/kota (Susanti, 2000). Pertumbuhan ekonomi di suatu daerah dapat dilihat / diukur dengan Produk Domestik Regional Bruto (PDRB). Pendapatan Domestik Regional Bruto pada dasarnya merupakan jumlah nilai tambah yang dihasilkan oleh seluruh unit usaha dalam suatu daerah tertentu, atau merupakan jumlah nilai barang dan jasa akhir yang dihasilkan oleh seluruh unit ekonomi pada suatu daerah. Pertumbuhan ekonomi Sumatera Selatan pada tahun 2019 mengalami penurunan dibandingkan dengan pertumbuhan ekonomi tahun-tahun sebelumnya. Laju pertumbuhan PDRB Sumatera Selatan tahun 2019 mencapai 5,71 persen atau menurun dibanding tahun sebelumnya sebanyak 0,33 persen (BPS, 2019).

Pada hakekatnya, faktor-faktor yang mempunyai kontribusi terhadap pembentukan Produk Domestik Regional Bruto (PDRB) adalah pertumbuhan penduduk dan tenaga kerja, selain itu juga dipengaruhi oleh tingkat investasi. Tingkat investasi yang rendah lebih cendrung memberikan pengaruh negatif bagi pertumbuhan. Penduduk yang bertambah dari waktu ke waktu dapat menjadi pendorong maupun penghambat pertumbuhan ekonomi. Hal ini disebabkan di negara maju penduduk mampu meningkatkan pertumbuhan ekonomi karena didukung oleh investasi yang tinggi, teknologi yang tinggi dan lain-lain. Akan tetapi berbeda dengan negara berkembang, kurangnya modal, teknologi yang masih sederhana, kurang ahlinya tenaga kerja, oleh karena itu pertumbuhan penduduk cendrung menjadi penghambat pertumbuhan ekonomi.

Banyaknya jumlah pengusaha akan berpengaruh terhadap permintaan tenaga kerja. Diasumsikan tidak ada perubahan jumlah pekerja pada perusahaan lain maka masuknya pengusaha baru akan menambah jumlah perusahaan, akibatnya jumlah permintaan akan tenaga kerja bertambah. Sektor swasta merupakan sektor yang cukup berpengaruh terhadap sektor lainnya, karena sektor swasta ini merupakan faktor yang cukup penting dalam perekonomian (Tarmizi, 2012). 


\section{Literature Review}

\subsection{Teori Pertumbuhan Ekonomi}

Proses petumbuhan ekonomi menurut Adam Smith dibedakan menjadi dua. Pertama, pertumbuhan output total. Menurut Adam Smith sumber daya alam yang tersedia merupakan wadah yang paling mendasar dari kegiatan produksi suatu masyarakat. Jumlah sumberdaya alam yang tesedia merupakan batas maksimum bagi pertumbuhan ekonomi. Maksudnya jika sumber daya ini belum digunakan sepenuhnya maka jumlah penduduk dan stok modal yang ada yang memegang peranan dalam pertumbuhan output. Tetapi pertumbuhan output tersebut akan berhenti jika semua sumberdaya alam tersebut digunakan secara penuh. Kedua adalah pertumbuhan penduduk. Jumlah penduduk akan meningkat jika tingkat upah yang berlaku lebih tingi dari tingkat upah subsisten yaitu tingkat upah yang pasa-pasan untuk hidup. Tingkat upah yang berlaku menurut Adam Smith di tentukan oleh tarik menarik antara kekuatan permintaan dan penawaran tenaga kerja. Sementara itu permintaan akan tenaga kerja akan ditenukan oleh stok modal dan tingkat output masyarakat. Oleh karena itu laju pertumbuhan permintaan tenaga kerja di tentukan oleh laju pertumbuhan stok modal (akumulasi modal) dan laju pertumbuhan output (Sukirno, 2012).

Menurut Teori Harrod Domar merupakan perluasan dari analisis Keynesian mengenai kegiatan ekonomi secara nasional dan masalah tenaga kerja. Dalam teorinya pembentukan modal merupakan faktor penting dalam menentukan pertumbuhan ekonomi.Pembentukan modal tersebut dapat diperoleh melalui akumulasi modal. Pembentukan modal tidak hanya dipandang sebagai pengeluaran yang akan menambah kemampuan suatu perekonomian untuk menghasilkan barang dan jasa tetapi juga akan meningkatkan permintaan efektif masyarakat. Teori ini menunjukan bahwa jika pada suatu periode tertentu dilakukan sejumlah pembentukan modal, maka pada masa berikutnya perekonomian tersebut akan mempunyai kemampuan yang lebih besar dalam menghasilkan barang dan jasa. Teori ini juga mengganggap bahwa kenaikan kapasitas produksi dan pendapatan nasional ditentukan oleh kenaikan pengeluaran masyarakat. Dengan demikian meskipun kapasitas produksi bertambah, pendapatan nasional baru akan mengalami kenaikan hanya jika terjadi kenaikan pengeluaran masyarakat (Sukirno, 2012).

Model ini menerangkan dengan asumsi bahwa perekonomian dapat mencapai pertumbuhan yang kuat (steady growth) dalam jangka panjang. Asumsi yang dimaksud disini adalah kondisi dimana barang modal telah mencapai kapasitas penuh, tabungan memiliki proporsional yang ideal dengan tingkat pendapatan nasional, rasio antara modal dengan produksi (capital output ratio/COR) tetap. Perekonomian terdiri dari dua sektor $(\mathrm{Y}=\mathrm{C}+\mathrm{I})$ (Hardinandar, 2019).

\subsection{Teori Pengeluaran Pemerintah}

Menurut Mangkoesoebroto (1993) dalam bukunya yang berjudul Ekonomi Publik, Pengeluaran pemerintah mencerminkan kebijakan pemerintah. Apabila pemerintah telah menetapkan suatu kebijakan untuk membeli barang dan jasa, pengeluaran pemerintah mencerminkan biaya yang harus dikeluarkan oleh pemerintah untuk melaksanakan kebijakan tersebut.

Model pembangunan tentang perkembangan pengeluaran pemerintah dikembangkan oleh Rostow dan Musgrave yang menghubungkan perkembangan pengeluaran pemerintah dengan tahap-tahap pembangunan ekonomi yang dibedakan antara tahap awal, tahap menengah, dan 
tahap akhir. Pada tahap awal disebut perkembangan ekonomi, persentase investasi pemerintah terhadap total investasi besar sebab pada tahap ini pemerintah harus menyediakan prasarana, seperti pendidikan, kesehatan, transportasi, dan sebagainya. Pada tahap menengah atau tahap pembangunan ekonomi, investasi pemerintah tetap diperlukan untuk meningkatkan pertumbuhan ekonomi agar dapat tinggal landas, namun pada tahap ini peranan investasi swasta sudah semakin membesar. Pada tahap ini peranan pemerintah masih tetap besar, namun karena peranan swasta yang semakin besar dapat menimbulkan kegagalan pasar, dan juga menyebabkan pemerintah harus menyediakan barang dan jasa publik dalam jumlah yang lebih banyak dan kualitas lebih baik (Rahardja, 2008).

Pada tingkat ekonomi yang lebih lanjut, Rostow mengatakan bahwa pembangunan ekonomi, aktivitas pemerintah beralih dari penyediaan prasarana ke pengeluaran - pengeluaran untuk aktivitas sosial seperti halnya, program kesejahteraan hari tua, program pelayanan kesehatan masyarakat dan sebagainya. Wagner mengemukakan suatu teori mengenai perkembangan teori pengeluaran pemerintah yang semakin besar dalam persentase terhadap GNP yang juga didasarkan pula pengamatan di negara-negara Eropa, U.S. dan Jepang pada abad ke-19. Wagner mengemukakan pendapatnya dalam hukum yaitu: Dalam suatu perekonomian, apabila pendapatan per kapita meningkat, secara relatif pengeluaran pemerintah pun meningkat. Dasar hukum teori tersebut pengamatan empiris dari negara - negara maju (USA, German, Jepang), tetapi hukum tersebut memberi dasar akan timbulnya kegagalan pasar dan eksternalitas. Wagner menyadari bahwa dengan bertumbuhnya perekonomian hubungan antara industri dengan industri,hubungan industri dengan masyarakat, dan sebagainya menjadi semakin rumit atau kompleks (Haryanto, 2013).

\subsection{Belanja Daerah}

Belanja daerah meliputi semua pengeluaran uang dari Rekening Kas Umum Daerah yang mengurangi ekuitas dana, yang merupakan kewajiban daerah dalam satu tahun anggaran yang tidak akan diperoleh pembayarannya kembali oleh daerah. Pasal 26 dan 27 dari Peraturan Pemerintah Nomor 58 Tahun 2005 tentang Pengelolaan Keuangan Daerah tidak merinci tentang klasifikasi belanja menurut urusan wajib, urusan pilihan, dan klasifikasi menurut organisasi, fungsi, program kegiatan, serta jenis belanja (Nailufar \& Sufitrayati, 2019).

\subsection{Tenaga Kerja}

Menurut UU Ketenagakerjaan No. 14 Tahun 1969, tenaga kerja adalah setiap orang yang mampu melakukan pekerjaan baik di dalam maupun di luar hubungan kerja guna menghasilkan barang atau jasa untuk memenuhi kebutuhan masyarakat. Tenaga kerja merupakan faktor penting bagi pembangunan. Jumlah angkatan kerja akan terus mengalami perubahan seiring dengan berlangsungnya proses demografi. Tenaga kerja merupakan penduduk dengan batas umur minimal 10 tahun tanpa batas maksimal. Pembangunan ketenagakerjaan mempunyai banyak dimensi dan saling berkaitan. Keterkaitan itu mencakup tenga kerja dengan pengusaha, pemerintah dan masyarakat. Namun seiring berjalannya waktu, Undang-Undang No. 25 tahun 1997 tentang ketenagakerjaan menetapkan batasan usia kerja menjadi 15 tahun yang mulai berlaku 1 Oktober 1998 (Tarmizi, 2012).

Tenaga kerja terdiri dari angkatan kerja dan bukan angkatan kerja. Angkatan kerja adalah penduduk yang sudah memasuki usia kerja. Baik yang sudah bekerja maupun belum bekerja atau sedang mencari pekerjaan. Menurut ketentuan pemerintah Indonesia, penduduk yang 
sudah memasuki usia kerja adalah berusia minimal 15 tahun sampai 65 tahun. Akan tetapi tidak semua penduduk yang memasuki usia kerja termasuk angkatan kerja. Sebab penduduk yang tidak akif dalam kegiatan ekonomi tidak termasuk dalam kelompok angkatan kerja. Misalnya ibu rumah tangga, pelajar, mahasiswa dan sebagainya. Dalam penelitian digunakan variabel tenaga kerja (angkatan kerja) yang bekerja karena jumlah angkatan kerja yang bekerja merupakan gambaran kondisi dari lapangan kerja yang tersedia dan mempengaruhi total produksi di suatu daerah (Tarmizi, 2012).

\section{Metode Penelitian}

Penelitian ini menggunakan data sekunder dalam bentuk time series (runtun waktu) periode 2006-2017. yaitu data yang sudah diterbitkan dan penulis kumpulkan yang bersumber dari kunjungan lapangan ke kantor Badan Perencanaan dan Pembangunan Daerah (BAPPEDA) Provinsi Sumatera Selatan, Dinas Pendapatan Daerah (DISPENDA) Provinsi Sumatera Selatan, Badan Pusat Statistik (BPS) Sumatera Selatan serta mengunjungi website kementerian keuangan (DPJK) dan CEIC.

Dalam penelitian ini akan menganalisis dampak belanja daerah terhadap ouput sektor swasta di Sumatera Selatan. Analisis yang digunakan adalah regresi linear berganda dengan formula sebagai berikut :

$$
\operatorname{lnPDRBs}=\alpha+\beta 1 \operatorname{lnBL}+\beta 2 \operatorname{lnBTL}+\beta 3 \operatorname{lnTK}+\mathrm{e}
$$

dimana:

$$
\begin{aligned}
& \text { PDRB = Output sektor Swasta (PDRB - Sektor Jasa Pemerintah) } \\
& \text { BL = Belanja Langsung } \\
& \text { BTL = Belanja Tidak Langsung } \\
& \text { TK }=\text { Tenaga Kerja } \\
& \text { ln = Logaritma Natural } \\
& \alpha \quad=\text { Intersep } \\
& \beta 1, \beta 2, \beta 3=\text { Koefisien Regresi } \\
& \mathrm{e}=\text { Komponen error }
\end{aligned}
$$

Model Regresi ini akan diestimasi dengan menggunakan metode Ordinary Least Square (OLS).

\section{Hasil dan Pembahasan}

Hasil estimasi pengaruh Belanja Daerah dan Tenaga Kerja terhadap Output Sektor Swasta secara rinci ditampilkan sebagai berikut ini:

$$
\begin{aligned}
& \text { PDRBs }=-82649975+11.34908 \mathrm{BL}+14.82232 \mathrm{BTL}+55.84045 \mathrm{TK} \\
& \mathrm{t} \text {-statistic } \quad=(-1.624909) \quad(3.297869) \quad(2.409417) \\
& \text { Probabilitas }=\left(\begin{array}{llll}
(0.1428) & (0.0109) & (0.0425) & (0.0138)
\end{array}\right. \\
& \text { F- Statistik }=95.26811(0.000001) \\
& \text { R2 } \quad 0.962560
\end{aligned}
$$

Nilai konstanta -82649975 menunjukkan bahwa jika variabel-variabel independen adalah 0, maka output sektor swasta sebesar -82649975. Koefisien belanja langsung menunjukkan angka 11.34908 yang artinya pada saat variabel lain sama dengan nol, peningkatan 1 juta pada belanja langsung akan berdampak terhadap variasi output sektor swasta sebesar 11,35 juta. Koefisien belanja tidak langsung menunjukkan angka 14.82232 yang artinya pada saat variabel lain sama dengan nol, peningkatan 1 juta pada belanja tidak langsung akan berdampak terhadap variasi output sektor swasta sebesar 14,8 juta. Koefisien Jumlah tenaga 
kerja menunjukkan angka 55.84045 yang artinya pada saat variabel lain sama dengan nol, peningkatan 1 juta tenaga kerja pada Jumlah tenaga kerja akan berdampak terhadap variasi output sektor swasta sebesar 55,84 juta. Probabilitas Gt1, Gt2 dan Nt yang masing-masing $0.0109,0.0425$ dan 0.0138 menunjukkan ketiga variabel berpengaruh signifikan terhadap PDRB sektor swasta.

\section{Simpulan}

Berdasarkan hasil analisis dan pembahasan yang telah dilakukan maka dapat ditarik kesimpulan beberapa hal di antaranya, secara parsial variabel belanja langsung, belanja tidak langsung, dan tenaga kerja berpengaruh positif dan signifikan terhadap output sektor swasta di Sumatera Selatan dan secara simultan seluruh variabel bebas berpengaruh signifikan terhadap output sektor swasta di Sumatera Selatan.

\section{Daftar Pustaka}

Arsyad, L. (1999). Pengantar Perencanaan Dan Pembangunan Ekonomi Daerah. Yogyakarta: BPFE-Yogyakarta.

BPS. (2019). Produk Domestik Regional Bruto Provinsi Sumatera selatan Menurut Pengeluaran 2015- 2019. BPS Provinsi Sumatera Selatan, 1-97.

Hardinandar, F. (2019). Determinan Kemiskinan (Studi Kasus 29 Kota/Kabupaten Di Provinsi Papua). Jurnal REP (Riset Ekonomi Pembangunan), 4(1), 1-12. https://doi.org/10.31002/rep.v4i1.1337

Haryanto, T. P. (2013). Pengaruh Pengeluaran Pemerintah Terhadap Pertumbuhan Ekonomi Kabupaten/Kota Di Provinsi Jawa Tengah Tahun 2007-2011. Economics Development Analysis Journal, 2(3), 148-158. https://doi.org/10.15294/edaj.v2i3.1989

Mangkoesoebroto, G. (1993). Ekonomi Publik (3rd ed.). Yogyakarta: BPFE.

Nailufar, F., \& Sufitrayati, S. (2019). Pengaruh Pendapatan Asli Daerah dan Dana Alokasi Khusus terhadap Belanja Daerah di Kota Banda Aceh. Jurnal Samudra Ekonomi Dan Bisnis, 10(1). https://doi.org/10.33059/jseb.v10i1.1126

Rahardja, M. (2008). PENGANTAR ILMU EKONOMI (MIKROEKONOMI \& MAKROEKONOMI). Jakarta: Lembaga Penerbit Fakultas Ekonomi Universitas Indonesia.

Sukirno, S. (2012). Makro Ekonomi Teori Pengantar (3rd ed.). Jakarta: PT Raja Grafindo Persada.

Susanti, H. (2000). Indikator-indikator Makro Ekonomi. Jakarata: LPFE-UI.

Tarmizi, N. (2012). Ekonomi Ketenagakerjaan. Palembang: Unsri Press.

Winoto, A. H., \& Falikhatun, F. (2015). Indikasi Penyalahgunaan Discretionary Fund Dalam Anggaran Pendapatan Dan Belanja Daerah Menjelang Pemilukada 2015. Jurnal Akuntansi Dan Keuangan Indonesia, 11(1), 75-91.

https://doi.org/10.21002/jaki.2015.05

\section{Copyright Disclaimer}

Copyright for this article is retained by the author(s), with first publication rights granted to the journal. 